\title{
Business Model Canvas Analysis on Cual weaving Industry
}

\author{
Syaiful $^{1}$, Chairul Furqon ${ }^{2}$, MokhAdib Sultan ${ }^{3}$ \\ Program Studi Manajemen, Sekolah Pascasarjana, UniversitasPendidikan Indonesia, Bandung, Indonesia ${ }^{1}$ \\ Program Studi Manajemen, FPEB, UniversitasPendidikan Indonesia, Bandung, Indonesia ${ }^{2}$ \\ Program Studi Manajemen, FPEB, UniversitasPendidikan Indonesia, Bandung, Indonesia ${ }^{3}$
}

\begin{abstract}
The purpose of this study was to describe the Business Model Canvas used by the weaving cualmaslina industry in Bangka Belitung. The type of the research used is qualitative descriptive. Data were collected through interviews, observations, and questionnaires. Data analysis was carried out through SWOT Analysis, EFAS/IFAS matrix, SWOT matrix, matrix combination of strategies and business model canvas analysis. This study found that the priority strategy that must be done by weaving cualMaslina is to utilize the product's uniqueness to attract goverment assistance and make a strong brand image to take advantage of business opportunities that are still wide open (SO). Analysis of Business Model Canvas on weaving cualMaslina found four elements that need to be improved; Customer segment forms a new segmentation, Channels works with business partners to create websites, Key activities form subdivisions of R\&D (quality control, design and coloring techniques), Key resources recruits HR Potential.
\end{abstract}

Keyword. Business Model Canvas; Analisis SWOT; EFAS/IFAS; Matriks SWOT.

Article history. Received Agustus, 2018. Revised Oktober, 2018.Accepted December, 2018

Corresponding Author. Email. Syaiful12@student.upi.edu

How to cite article. Furqon, C., \& Sultan, M. (2018). Business Model Canvas Analysis on Cual weaving Industry. The International Journal of Business Review (The Jobs Review), 1(2), 115-122. https://doi.org/https://doi.org/10.17509/tjr.v1i2.14108

\section{INTRODUCTION}

Indonesia is a developed country with the 4th largest population in the world. Poverty and unemployment in Indonesia are the main problems since the colonial era. The solution to solve these problems is to develop organized small and medium enterprises (SMEs) that are directed at creating jobs and increasing and leveling the income of the entire community economy(Fiseha\&Oyelana, 2015). (Taiwo, Ayodeji, \& Yusuf, 2014), SMEs contribute positively to the development of the Nigerian economy. In 2017, the contribution of the SME sector to gross domestic product increased from $57.84 \%$ to $60.34 \%$ in the last five years. And labor absorption rose from $96.99 \%$ to $97.22 \%$ (kemenperin). (Mustafa, 2017)SMEs not only have an impact on GDP but also help people's livelihoods by creating more economic opportunities in Pakistan.

One of the examples of various SMEs with diverse fields of businessesis woven cloth. Woven Fabric is one of Indonesia's original crafts that has a distinctive style as part of the richness representations of local culture. In Bangka Belitung, the center of regional handcraft woven cloth regency is Pangkal Pinang. Speaking of cloth weaving type, Bangka Belitung region also has a regional weaving that has been developing since the 18th century named TenunCual.

Based on interviews with the head of Cooperation and KUKM on cual weaving SMEs, found that the performance of cual weaving SMEs in Bangka Belitung in the past three years had not reached the expected target. Table 1. presents target data for the achievement of business performance of cual weaving SMEs which are still below $100 \%$. 


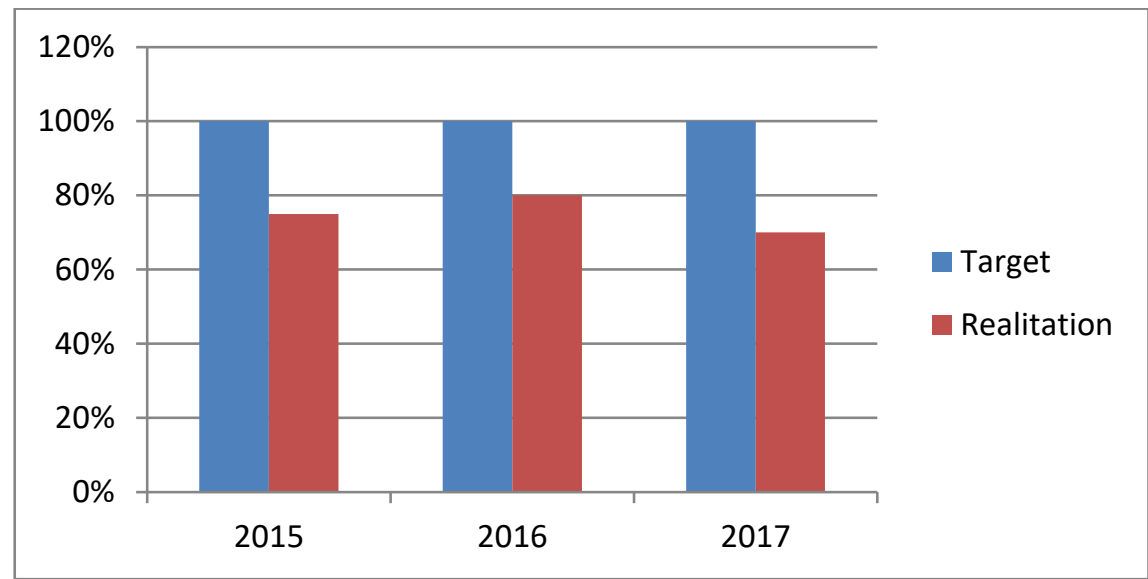

Figure 1. Business Performance of weaving cual industry ( 2015-2017)

Source: cooperation official and KUKM Bangka Belitung province 2018

The level of achievement of the Cual Weaving SME business performance shows a gap between target and realization. The assumption is that this indicates that the performance of weaving SMEs is not maximal. This can be caused by a lot of factors;(Purwaningsih\&Kusuma, 2015) internal and external factors. According to(Xiaoying, Qianqian, \&Dezhi, 2008)the factors that influence business performance are information systems, and business strategies.

Internal (IFAS) and external analysis (EFAS) is the beginning of the process of strategy formulation. (Tante, 2013), EFAS and IFAS are analyzes based on the ability to see the strengths and weaknesses of the business from internal and external of certain companies. The aim is to analyze the situation, the conditions in arranging strategy formula of the company.

(Faruq \& Usman, 2016)business strategy is an integrated and coordinated sequence of commitments and actions designed to exploit main competencies and achieve competitive advantage. One business strategy that can be used is to choose a business model. A business model is a model that describes the rationale for how organizations capture and create value(Slávik\&Bednár, 2014). (Viljakainen, Toivonen, \&Aikala, 2013), an established business model, companies are able to determine the direction by identifying in terms of markets, competitors and customers and creating competitive advantage in the market.

One business model that is feasible to use is Business Model Canvas (BMC). Model Canvas Business is one of the business strategies that can design, illustrate to conclude business aspects into a single strategy and map business more simply and efficiently. (Osterwalder\&Pigner, 2017),(Nur et al., 215)The Business Model Canvas describes nine block components to design business strategies, they are:customer segments, value propositions, channels, customer relationships, revenue streams, resources, activities, partnerships, and cost structure. (Dudin, Kutsuri, Fedorova, Dzusova, \&Namitulina, 2015)BMC is a solution in assessing companies and company strategies. (Erlyana\& Hartono, 2017)The BMC along with the SWOT analysis explains how the XYZ online store creates, delivers and captures values based on the external and internal environment.

\section{RESEARCH METHOD}

This research was conducted at the cual Maslina Weaving located in Pangkal Pinang, Bangka Belitung. This research was conducted using a qualitative descriptive method through a case study approach. The data used in this study are primary and secondary data. 
Primary data were obtained from the results of interviews with research informants. The informants consisted of internal companies, who are the owner of weaving cualmaslina, the manager of the store and the external consumers and the surrounding community. The secondary data is in the form of documents, books, journals and internet. Data collection techniques in this study were carried out through 1). Interviews and questionnaires, interview techniques are conducted in the form of discussion and two-way communication by including a list of questions that had been prepared in advance. 2) observation through supervision and records of the agencies involved in the study. 3) documentation obtained through a number of data and information in the field in the form of administrative documents obtained through interviews, observations and secondary data

\section{RESULTS AND DISCUSSION}

\section{Tabel 1 SWOT Analysis on the weaving Cual Maslina}

\begin{tabular}{|c|c|}
\hline Strengths & $\begin{array}{l}\text { 1. Using premium ingredients quality } \\
\text { 2. Having product uniqueness } \\
\text { 3. A strong brand image in the } \\
\text { community }\end{array}$ \\
\hline Weaknesses & $\begin{array}{l}\text { 1. Expensive price } \\
\text { 2. The production process which is } \\
\text { still traditional } \\
\text { 3. Don't have a website } \\
\text { 4. The location is hard to reach }\end{array}$ \\
\hline Opportunities & $\begin{array}{l}\text { 1. Business opportunities are wide } \\
\text { open } \\
\text { 2. Government assistance to the cual } \\
\text { weaving industry } \\
\text { 3. Partnering with customer to } \\
\text { increase innovation opportunities } \\
\text { 4. Shopping tour and education }\end{array}$ \\
\hline Threats & $\begin{array}{l}\text { 1. Technological advancements } \\
\text { 2. The rising price of raw materials } \\
\text { 3. More competitive competitor } \\
\text { products } \\
\text { 4. Emergence of new competitor with } \\
\text { the same product }\end{array}$ \\
\hline
\end{tabular}

The SWOT analysis assists companies in analyzing and identifying internal and external factors to facilitate the company's internal management in developing alternative strategies(Permadi\&Nurmalina, 2016)

Tabel 2 matrix EFAS weavingCual Maslina

\begin{tabular}{|l|l|l|l|l|}
\hline Code & External Factor & Weight & Rating & Score \\
\hline Opportunities & $\begin{array}{l}\text { Business opportunities are } \\
\text { wide open }\end{array}$ & 0.17 & 3 & 0.51 \\
\hline O1 & $\begin{array}{l}\text { Government assistance to the } \\
\text { cual weaving industry }\end{array}$ & 0.10 & 3 & 0.30 \\
\hline O3 & $\begin{array}{l}\text { Partnering with customer to } \\
\text { increase innovation } \\
\text { opportunities }\end{array}$ & 0.22 & 3 & 0.66 \\
\hline 04 & Shopping tour and education & 0.11 & 3 & 0.33 \\
\hline
\end{tabular}

117 | The International Journal of Business Review (The Jobs Review) Vol.1 | No.2 | 2018 
SYAIFUL, CHAIRUL FURQON, MOKHADIB SULTAN/Business Model Canvas Analysis on Cual Weaving Industry

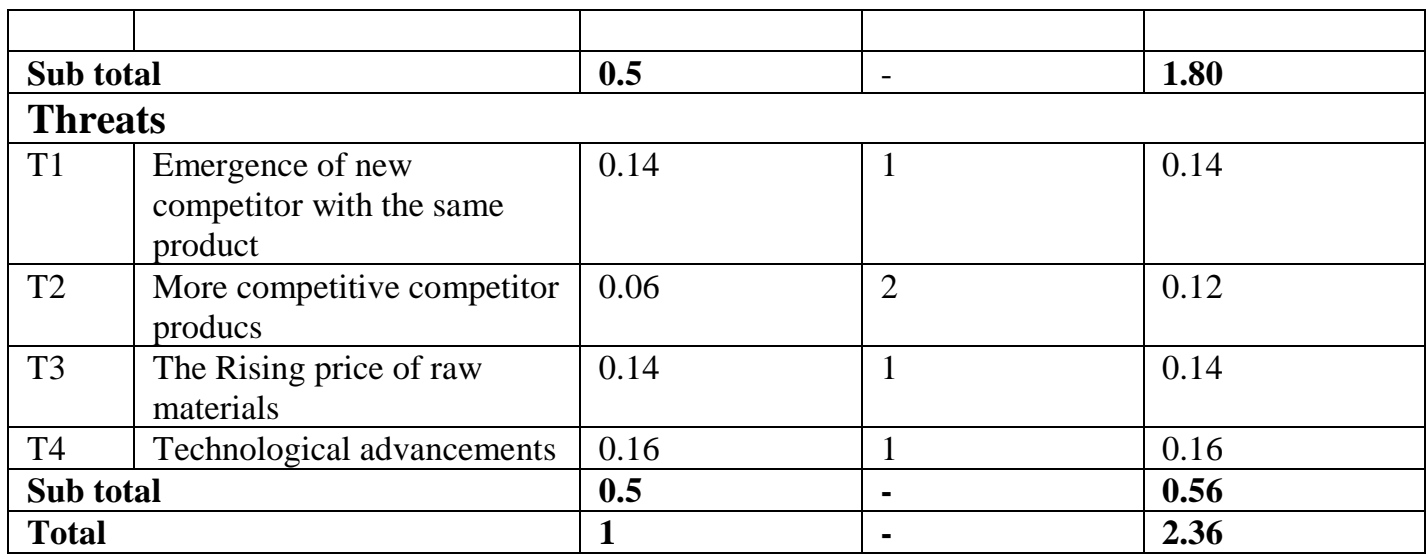

Based on the EFAS matrix, the sub score of total strength is 1.80 , while the weaknesses in sub-total scores is 0.56 , so the total EFAS score is 2.36

Tabel 3 matrix IFAS weaving Cual Maslina

\begin{tabular}{|l|l|l|l|l|}
\hline Code & Internal Factor & Weight & Rating & Score \\
\hline Strengths & \multicolumn{4}{l|}{} \\
\hline S1 & $\begin{array}{l}\text { Using premium ingredients } \\
\text { quality }\end{array}$ & 0.17 & 4 & 0.68 \\
\hline S2 & Having product uniqueness & 0.15 & 3 & 0.45 \\
\hline S3 & $\begin{array}{l}\text { A strong brand image in the } \\
\text { community }\end{array}$ & 0.18 & 4 & 0.72 \\
\hline Sub total & $\mathbf{0 . 5}$ & - & $\mathbf{1 . 8 5}$ \\
\hline Weaknesses & 0.15 & 1 & 0.15 \\
\hline W1 & Expensive price & 2 & 0.22 \\
\hline W2 & $\begin{array}{l}\text { The production process } \\
\text { which is still traditional }\end{array}$ & 0.11 & 1 & 0.15 \\
\hline W3 & Don't have a website & 0.15 & 2 & 0.18 \\
\hline W4 & The location is hard to reach & 0.09 & - & $\mathbf{0 . 7 0}$ \\
\hline Sub total & $\mathbf{0 . 5}$ & - & $\mathbf{2 . 5 5}$ \\
\hline \multicolumn{2}{|l|}{ Total } & $\mathbf{1}$ & 1 & \\
\hline
\end{tabular}

Based on the IFAS matrix, the score of opportunity total is 1.85 , while the score of sub threats is 0.70 , so the total score of IFAS is 2.55

\begin{tabular}{|c|c|c|}
\hline $\begin{array}{r}\text { Internal factor } \\
\text { (IFAS) }\end{array}$ & \begin{tabular}{ll} 
& \multicolumn{1}{c}{ Strength $(\mathbf{S})$} \\
1. & Using premium ingredients \\
quality
\end{tabular} & $\begin{array}{l}\text { Weakness }(\mathbf{W}) \\
\text { 1. Expensive price } \\
\text { 2. The production process } \\
\text { which is stil traditional } \\
\text { 3. Don't have a website } \\
\text { 4. The location is hard to } \\
\text { reach }\end{array}$ \\
\hline $\begin{array}{l}\text { Opportunities }(\mathbf{O}) \\
\text { 1. } \begin{array}{l}\text { Business opportunities are } \\
\text { wide open }\end{array} \\
\text { 2. } \begin{array}{l}\text { Partnering with customer } \\
\text { to increase innovation } \\
\text { opportunities }\end{array} \\
\end{array}$ & $\begin{array}{l}\text { Strategi SO } \\
\text { Utilize product uniqueness to } \\
\text { attract assistance from the } \\
\text { government } \\
\text { Make a strong brand image to } \\
\text { take advantage of business }\end{array}$ & $\begin{array}{l}\text { Strategi WO } \\
\text { Maintain and attract new } \\
\text { customers by establishing good } \\
\text { relationships so that market } \\
\text { share is not limited to location } \\
\text { Business opportunities are wide } \\
\text { open both in local and }\end{array}$ \\
\hline
\end{tabular}

118 | The International Journal of Business Review (The Jobs Review) Vol.1 | No.2 | 2018 


\begin{tabular}{|c|c|c|}
\hline $\begin{array}{l}\text { 3. Government assistance to } \\
\text { the cual weaving industry } \\
\text { 4. Shopping tours and } \\
\text { education }\end{array}$ & $\begin{array}{l}\text { opportunities that are still wide } \\
\text { open } \\
\text { Product with premium } \\
\text { ingredients quality are designed } \\
\text { into tools to maintain good } \\
\text { relationship with customers }\end{array}$ & $\begin{array}{l}\text { international markets where the } \\
\text { buyers do not look at price but } \\
\text { rather the beauty and quality of } \\
\text { weaving. }\end{array}$ \\
\hline 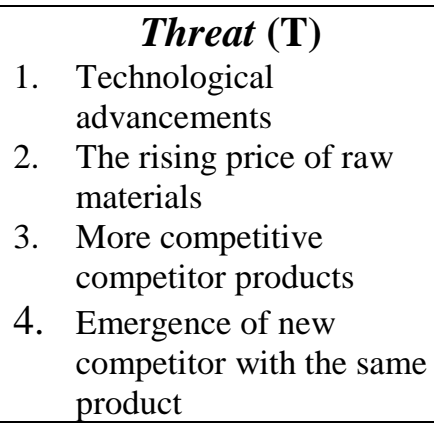 & $\begin{array}{l}\text { Strategi ST } \\
\text { Expand market share by utilizing } \\
\text { product uniqueness and } \\
\text { technological advancments, } \\
\text { quality and premium material }\end{array}$ & $\begin{array}{l}\text { Make use of technological } \\
\text { advancements to create website } \\
\text { as a digital marketing media }\end{array}$ \\
\hline
\end{tabular}

Based on the SWOT strategy combination matrix, there are several strategies that need to be applied by the cual maslina weaving industry in Pangkal Pinang, these strategies are from SO, ST, WT and WO strategies.

SO (Strength-Opportunity)

$\checkmark$ S2,O3 (utilize the uniqueness of the product to attract assistance from the government)

$\checkmark$ S3,O1 (make a strong brand image to take advantage of business opportunities that are still wide open))

ST (Strength-Threat)

$\checkmark$ S2,T1 (expand market share by utilizing the product uniqueness and technological progress)

\section{WO (Weakness-Opportunity)}

$\checkmark$ W4,O2 (maintain and capture new customers by establishing good relationships so that market share is not limited to location)

\section{WT (Weakness-Threat)}

$\checkmark$ W3,T1 (utilize technological advancements to create websites as digital marketing media)

Tabel 5. Strategy combination planning matrix

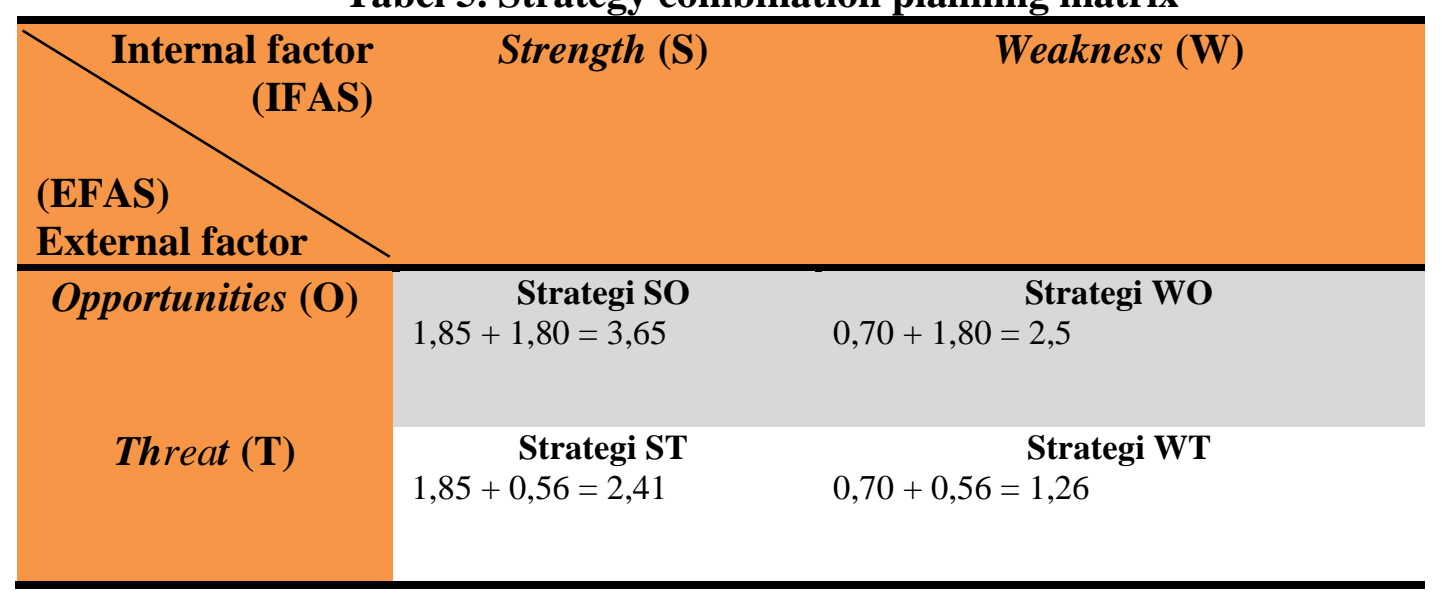

The quantitative strategy combination planning matrix table shows that the cual maslina weaving industry in Pangkal Pinang needs to prioritize the SO strategy which has the highest score of 3.65. Then followed by the WO strategy of 2.5, the ST strategy of 2.41 
and the WT strategy of 1.26 . The respective strategies are utilizing the uniqueness of the product to attract assistance from the government, making a strong brand image to take advantage of business opportunities that are still wide open, expanding market share by utilizing product uniqueness and technological progress, maintaining and capturing new customers by establishing relationships that both so that the market share is not limited by location, utilizing technological advancements to create websites as digital marketing media.

Analysis of the Business Model canvas on weaving Cual Maslina

\begin{tabular}{|c|c|c|c|c|}
\hline \multirow[t]{2}{*}{$\begin{array}{l}\text { Key Partner } \\
\text { Supplier of raw } \\
\text { materials } \\
\text { Provincial } \\
\text { government of } \\
\text { Bangka Belitung }\end{array}$} & $\begin{array}{l}\text { Key Activities } \\
\text { Design } \\
\text { Production } \\
\text { Service }\end{array}$ & \multirow[t]{2}{*}{\begin{tabular}{l}
\multicolumn{1}{c}{ Value } \\
Proposition \\
Woven cual of the \\
region with \\
distinctive designs \\
and colors
\end{tabular}} & $\begin{array}{l}\text { Customer } \\
\text { Relationship } \\
\text { Discounts on } \\
\text { members Personal } \\
\text { approach }\end{array}$ & \multirow{2}{*}{\begin{tabular}{l}
\multicolumn{1}{c}{$\begin{array}{c}\text { Customer } \\
\text { Segment }\end{array}$} \\
Banka Belitung \\
government staffs \\
Tourists who are \\
on vacation in \\
Bangka Belitung
\end{tabular}} \\
\hline & $\begin{array}{l}\text { Key Resource } \\
\text { Housewives } \\
\text { The quality of } \\
\text { human } \\
\text { resources'IT is } \\
\text { low }\end{array}$ & & $\begin{array}{l}\text { Channels } \\
\text { Regional and } \\
\text { national } \\
\text { exhibitions }\end{array}$ & \\
\hline \multicolumn{2}{|c|}{ Cost Structure } & \multicolumn{3}{|c|}{ Revenue stream } \\
\hline \multicolumn{2}{|c|}{$\begin{array}{l}\text { Employees salary } \\
\text { Operational activities cost }\end{array}$} & \multicolumn{3}{|l|}{$\begin{array}{l}\text { Online/Offline sale } \\
\text { Workshop/training }\end{array}$} \\
\hline
\end{tabular}

Figure 2. Business Model Canvas of weaving cual maslina

BMC acts as a link in creating value for customers, for companies, and to help companies in scanning external and internal environments (Ahokangas\&Myllykoski, 2014; Lynch, 2013), creating a proportion of value from opportunity investment (Jesper C. Sort and Christian Nielsen, 2018)

BMC weaving of cual maslina conditions is obtained based on the results of interviews with informants which then produce accurate information about the Nine BMC elements on cual maslina weaving. The process of identifying the nine aspects involved the owner and head of the Bangka Belitung KUKM office. The resource person is considered to have the capacity to provide accurate information related to the data needed to identify nine BMC elements for the latest portrait of the current business of the Indonesian woven cual business. The current results of the identification of the nine BMC blocks on the cual maslina weaving are as follows:

1. Customer segment

Cual maslina weaving customers in Pangkal Pinang has a different segment, such as the Bangka Belitung Provincial Government and tourists.

2. Value proposition

Value proposition offered by cual maslina weaving in Pangkal Pinang is a distinctive design and color.

3.Channels

Cual maslina weaving industry in Pangkal Pinang utilizes exhibitions provided by the government and the private sector in delivering its value proposition.

4. Relationship cutomer 
The way cual maslina weaving industry method at Pangkal Pinang maintain good relations with its customers, is by giving discounts to customer members, and personal approaches.

5. Revenue streams

Cual maslina weaving industry income in Pangkal Pinang, weaving training workshops, online and offline sales.

6 Key resource

Important resource that are needed by the cual maslina weaving industry in Pangkal Pinang are human resources; housewives, and the improvement ofIT of human resources.

7. Key activities

The activities carried out in operating the cual maslina weaving business are still running including designing product, manufacture and sales service.

8. Key partnership

Cual maslina weaving industry business associates in Pangkal Pinang currently are suppliers of raw materials, and provincial of Bangka Belitung government.

9. Cost structure

Costs incurred by the cual maslina weaving industry are employee salaries, raw materials, and costs operational industrial activities such as joining the exhibition, logistics etc.

\section{CONCLUSION}

1. Based on the results of the discussion on, SWOT Analysis, TOWS Matrix and EFAS / IFAS on weaving cualmaslina, concluded that the priority strategy that must be done by weaving cualmaslina is to utilize the product's uniqueness to attract government assistance and make a strong brand image take advantage of business opportunities that are still wide open (SO)

2. Based on the results of discussions on Business Model Canvas on woven cual maslina there are several aspects that need to be improved, they are:

a. Customer segment is still limited to local government officials and tourists, while its competitors already have a wider market share

b. Channels work with business partners to create websites

c. Key activities form a subdivision of $R \& D$ (quality control, design and coloring techniques)

d. Key resources recruit potential HR

\section{REFERENCES}

Ahokangas, P., \&Myllykoski, J. (2014). The Practice of Creating and Transforming a Business Model, 2(1), 6-18.

Dudin, M. N., Kutsuri, G. N., Fedorova, I. J. evna, Dzusova, S. S., \&Namitulina, A. Z. (2015). The innovative business model canvas in the system of effective budgeting. Asian Social Science, 11(7), 290-296. https://doi.org/10.5539/ass.v11n7p290

Erlyana, Y., \& Hartono, H. (2017). Business model in marketplace industry using business model canvas approach: An e-commerce case study. IOP Conference Series: Materials Science and Engineering, 277(1). https://doi.org/10.1088/1757-899X/277/1/012066

Faruq, M. A., \& Usman, I. (2016). PenyusunanStrategiBisnis Dan StrategiOperasi Usaha Kecil Dan MenengahPada Perusahaan Konveksi Scissors Di Surabaya. JurnalManajemenTeori Dan Terapan | Journal of Theory and Applied Management, 
7(3), 173-198. https://doi.org/10.20473/JMTT.V7I3.2710

Fiseha, G. G., \&Oyelana, A. A. (2015). An Assessment of the Roles of Small and Medium Enterprises (SMEs) in the Local Economic Development (LED) in South Africa. Journal of Economics, 6(3), 280-290. https://doi.org/10.1080/09765239.2015.11917617

Jesper C. Sort and Christian Nielsen. (2018). Using the business model canvas to improve investment processes. Jounal of Research in Marketing and Entrepreneurship, 20(1), 10-33. https://doi.org/10.1108/JRME-11-2016-0048

Lee, H. A., DenizciGuillet, B., \& Law, R. (2013). An Examination of the Relationship between Online Travel Agents and Hotels: A Case Study of Choice Hotels International and Expedia.com. Cornell Hospitality Quarterly, 54(1), 95-107. https://doi.org/10.1177/1938965512454218

Lynch, R. (2013). Strategic Management. Learning Person.

Mustafa, S. (2017). SMEs and its Role in Economic and Socio-Economic Development of Pakistan, 7(4), 195-205. https://doi.org/10.6007/IJARAFMS/v7-i4/3484

Nur, A., Amanullah, A. A., Faizah, N., Aziz, A., Hanis, F. N., Hadi, A., \& Ibrahim, J. (2015). Comparison of Business Model Canvas (BMC) Among the Three Consulting Companies. ISSN International Journal of Computer Science and Information Technology Research ISSN, 3(2), 2348-1196.

osterwalder\&pigner. (2017). Business Model Generation. New Jersey: John wiley\& sons, Inc.

Permadi, B., \&Nurmalina, R. (2016). AnalisisPengembangan Model BisnisKanvas CV KanduraKeramik Bandung, 88.

Purwaningsih, R., \&Kusuma., Kusuma, P. D. (2015). AnalisisFaktor-faktor Yang MempengaruhiKinerja Usaha Kecil danMenengah (UKM) DenganMetode Structural Equation Modeling (Studikasus UKM berbasisIndustriKreatif Kota Semarang). Seminar NasionalSains Dan Teknologi (SNST) Ke-6, (2000), 7-12.

Slávik, Š., \&Bednár, R. (2014). Analysis of Business Models. Journal of Competitiveness, 6(4), 19-40. https://doi.org/10.7441/joc.2014.04.02

Taiwo, M., Ayodeji, A., \& Yusuf, B. (2014). Impact of small and medium enterprises on economic growth and development. American Journal of Business Management, 2(July), 19-24.

Tante, S. I. (2013). BUSINESS STRATEGY PLANNING FOR MAKARONI CAKALANG FROM RANSUM, 2139-2150.

Viljakainen, A., Toivonen, M., \&Aikala, M. (2013). Industry transformation towards service logic: A business model approach, 1-24. Retrieved from http://www.cambridgeservicealliance.org/uploads/downloadfiles/2013_December_Ind ustry transformation towards service logic_A BM approach.pdf

Xiaoying, D., Qianqian, L., \&Dezhi, Y. (2008). Business Performance, Business Strategy , and Information System Strategic Alignment: An Empirical Study on Chinese Firms. Tsinghua Science and Technology, 13(3), 348-354. https://doi.org/10.1016/S10070214(08)70056-7 